\title{
Long-term impacts of silvicultural treatments on wildland fuels and modeled fire behavior in the Ridge and Valley Province, Virginia (USA)
}

\author{
George E. Hahn ${ }^{\text {a }}$, T. Adam Coates ${ }^{\text {a, }}$, W. Michael Aust ${ }^{\text {a }}$, M. Chad Bolding ${ }^{\text {a }}$, \\ Melissa A. Thomas-Van Gundy ${ }^{\text {b }}$
}

${ }^{a}$ Department of Forest Resources and Environmental Conservation, Virginia Polytechnic Institute and State University, Blacksburg, VA 24061, USA

${ }^{\mathrm{b}}$ United States Department of Agriculture Forest Service, Northern Research Station, Parsons, WV 26287, USA

\section{A R T I C L E I N F O}

\section{Keywords:}

BehavePlus

Clearcut

Duff

Litter

Shelterwood

Time-lag

\begin{abstract}
A B S T R A C T
Active forest management operations, such as regeneration harvests, can reduce hazardous fuel loads and alter fuel structure, potentially minimizing extreme wildfire conditions while maintaining ecosystem services, such as wildlife habitat and water quality. Regeneration harvests of differing intensities (clearcut, high-retention shelterwood, and low-retention shelterwood) were first applied between 1995 and 1996 to three sites on the George Washington-Jefferson National Forest in the Ridge and Valley Province of Virginia, USA. Over two decades after the clearcut was conducted and 11-12 years after the overwood was removed in the shelterwood stands, woody debris, litter, and duff masses and depths were quantified. One-hour fuel loads were greater in clearcut units than in high-retention shelterwood, low-retention shelterwood, or control units. Ten-hour fuel loads were greater in clearcut and low-retention shelterwood units than in high-retention shelterwood and control units. No significant differences in 100-hour fuels were observed between treatments. Control units contained more rotten and total 1000-hour fuels than all other treatments. The total woody debris load was less in the clearcut and high-retention shelterwood than in the low-retention shelterwood and control. High-retention shelterwood woody fuel depth was greater than clearcut woody fuel depth. Litter and duff loads were less in treated units than in the control units. Total fuel load (woody fuel load + litter load + duff load) was greater in the control than the silvicultural treatments. Litter depth did not differ between treatments, while duff depth was greater in the control than in the treated units. Using the computer modeling software, BehavePlus 6.0.0, these alterations to fuel loads and depths led to increased values in the control units for six fire behavior parameters. Predicted surface flame length in the low-retention shelterwood was the only modeled value that was not less than control values. Overall, these results indicated that harvest intensity and timing may have long-term effects on down and dead woody fuels, forest floor depth, and potential fire behavior. Clearcutting reduced fire behavior most, followed by the highretention shelterwood system. The potential differences in slash and debris generated by varying shelterwood systems may impact long-term fuel and fire dynamics.
\end{abstract}

\section{Introduction}

Since 2013, over 50\% of the United States Forest Service's discretionary funding has been allocated for wildfire suppression activities (Congressional Research Service 2018). Current wildfire projections through the year 2100 include increased wildfire size, suppression costs, and resource usage in highly developed areas and longer wildfire seasons (Collins and Knutti 2013, Abatzoglou and Williams 2016).
Specifically, forests of the southeastern United States are projected to experience extended periods of drought, increased wildfire incidence, and narrower windows in which prescribed fire may appropriately be utilized (Mitchell et al. 2014, Kupfer et al. 2020). For this reason, fuel reduction has increasingly been targeted in forest management plans to reduce potential wildfire ignitions, mitigate extreme fire behavior, and reduce subsequent, negative wildfire effects, such as increased soil erosion (Robichaud et al. 2008, Moody and Martin 2009, Robichaud

Abbreviations: ANOVA, Analysis of Variance; CC, clearcut; C, control; DBH, diameter at breast height; HS, high-retention shelterwood; LS, low-retention shelterwood; HSD, Tukey's Honest Significant Difference.

* Corresponding author at: 228F Cheatham Hall, 310 West Campus Dr., Blacksburg, VA 24061, USA.

E-mail address: acoates4@vt.edu (T.A. Coates). 
et al. 2014), air pollution (Goodrick et al. 2012, Liu et al. 2016, Cascio 2018), and residual tree damage or mortality (O'Brien et al. 2010, Varner et al. 2016, Schweitzer et al. 2019, Kreye et al. 2020).

Research investigating fuel reduction treatments in the Ridge and Valley Province and Appalachian Mountains of the United States is needed. Wildfire incidence within this region is predicted to increase through 2060 (Prestemon et al. 2016). Previous fuel reduction studies conducted in this region have generally included prescribed fire, either alone or in conjunction, with mechanical treatments (Waldrop et al. 2016, Vaughan 2020). Applying prescribed fire to forests of the Appalachian Mountains can be limited by short burn windows and a lack of public support and qualified personnel (Ryan et al. 2013), therefore mechanical treatments are often applied to alter potentially hazardous fuel loads and vertical fuel structure. A common mechanical fuel reduction method is the mastication of shrubs and small diameter stems (McIver et al. 2009, Stottlemyer et al. 2015). This method generally increases fuel loads in the short-term and can be costly to implement (Jernigan et al. 2016, Waldrop et al. 2016).

Few studies in the eastern United States have quantified fuel loads and potential fire behavior following the removal of overstory stems, either following intermediate treatments, such as commercial thinnings (Waldrop et al., 2008; Vander Yacht et al., 2019) or regeneration harvests (Brose 2016). Most previous research studies have compared fuel loads 3-5 years post-treatment (Graham and McCarthy 2006, Stephens et al. 2009, Phillips and Waldrop 2013, Brose 2016). Quantifying longterm effects of timber harvests on fuel loads and potential fire behavior will address a critical knowledge gap for forest managers in the eastern United States and in other locations with similar land management goals around the globe. If commercial timber harvests can reduce fuel loads and generate income, wildfire risk might be mitigated and incentivized on both private and public lands. In a study of pine plantations in northwestern Spain, Arellano-Pérez et al. (2020) found that the likelihood of active crown fires could be reduced with thinning treatments alone. However, fire severity and soil erosion were not greatly reduced with thinning alone. The authors determined that surface fuel treatments were also needed to achieve the desired severity and erosion reductions. In another study of thinning treatments in south Australia, Cruz et al. (2017) determined that a combination of pruning and thinning was most effective for altering fuel vertical structure and reducing fireline intensity.

The objectives of this study were to measure and compare: 1) down and dead woody fuel loads and depths, 2) O Horizon loads and depths, and 3) predicted fire behavior across 3 different silvicultural treatments (clearcut, low-retention shelterwood, high-retention shelterwood) over two decades after their initial implementation in Virginia's Ridge and Valley Province. Hypotheses for this study were: a) 1 -hour $(0-0.64 \mathrm{~cm}$ diameter), 10-hour (0.65-2.54 cm diameter), and 100-hour (2.55-7.62 $\mathrm{cm}$ diameter) down and dead woody fuel loads would be greatest following the low-retention shelterwood treatment when compared to other treatments and the control, while 1000-hour ( $>7.62 \mathrm{~cm}$ diameter) fuel loads would be greatest in the high-retention shelterwood treatment; b) total (woody + O Horizon) fuel loads would be greatest in the control followed by the low-retention shelterwood, high-retention shelterwood, and clearcut; c) woody fuel depths would be greater in treated units than in control units and $O$ Horizon depths would be greater in control units than in treated units; d) predicted fire behavior would be greatest in the control.

\section{Materials and methods}

\subsection{Study areas}

Three sites were utilized for this study: Blacksburg 1 (BB1), Blacksburg 2 (BB2), and New Castle (NC). All sites are in the Eastern Divide Ranger District of the Jefferson National Forest (Fig. 1; Table 1). The BB1 and BB2 sites are located in Montgomery County, Virginia (BB1: $37.29316^{\circ} \mathrm{N}, 80.45621^{\circ} \mathrm{W}$; BB2: $37.30518^{\circ} \mathrm{N}, 80.44048^{\circ} \mathrm{W}$ ) and contain mixed-hardwood stands (approximately 110 years old). Common species present are chestnut oak (Quercus montana Willd.), white oak (Quercus alba L.), American beech (Fagus grandifolia Ehrh.), and red maple (Acer rubrum L.). The mean annual temperature range is $2{ }^{\circ} \mathrm{C}$ (Winter) to $21^{\circ} \mathrm{C}$ (Summer). Annual precipitation is $1030 \mathrm{~mm}$ (Hammond 1997, Wender 2000, Sucre 2008, Atwood et al. 2009). Soils at the BB1 and BB2 sites consist mainly of the Jefferson series (Ultisols; Typic Hapludults) (USDA-NRCS 2015a).

The New Castle (NC) site is located in Craig County, Virginia $\left(37.455216^{\circ} \mathrm{N}, 80.382528^{\circ} \mathrm{W}\right)$ and contains an approximately 70 -yearold mixed-hardwood stand (Atwood et al. 2009). Common species listed for BB1 and BB2 are also present at the NC site. Mean annual temperature range is $2{ }^{\circ} \mathrm{C}$ (Winter) to $21^{\circ} \mathrm{C}$ (Summer). Annual precipitation is $950 \mathrm{~mm}$ (Hammond 1997, Wender 2000, Sucre 2008, Atwood et al. 2009). Soils at the NC site consist mainly of the Oriskany series (Ultisols; Typic Hapludults) (USDA-NRCS 2015b).

\subsection{Silvicultural treatments}

Four, 2-ha stands were treated at each site (Fig. 1). Silvicultural treatments were as follows (Table 2): a) clearcut (CC; in which all woody stems $>5 \mathrm{~cm}$ diameter at breast height (DBH) were felled, regardless of height - merchantable stems were removed and non-merchantable stems were left on-site); b) high-retention shelterwood (HS; in which overtopped and intermediate stems were removed, leaving $12-15 \mathrm{~m}^{2} \mathrm{ha}^{-1}$ of dominant or co-dominant stems); c) low-retention shelterwood (LS; in which dominant and co-dominant trees were removed, leaving 4-7 $\mathrm{m}^{2}$ $\mathrm{ha}^{-1}$ of trees $5-25 \mathrm{~cm} \mathrm{DBH}$ ); and d) control (C) with no treatment. No more than 10 stems ha ${ }^{-1}$ of mast, snag, or cull trees were left on-site in the CC unit to maintain wildlife habitat (Hood 2001).

The CC harvests and initial shelterwood cuts at all three locations began in 1995 and were completed in 1996 (Atwood et al. 2009). The overwood removal harvests in the shelterwood stands were completed in 2007 (BB1) and 2008 (BB2, NC) (Howell et al. 2021, in preparation).

\subsection{Study design and field measurements}

The silvicultural treatments at BB1, BB2, and NC were established in a randomized complete block design with each stand serving as a block (Hammond 1997, Wender 2000, Hood 2001, Sucre 2008, Atwood et al. 2009). Fuels within three replications of the CC, HS, LS, and C were quantified in our June - August 2019 assessment, yielding a total of 12 stands.

Within each of the 12 stands, 16 fuel inventory plots were established on a $30.5 \mathrm{~m} \times 30.5 \mathrm{~m}$ grid. Down and dead woody fuels were tallied using a modified version of Brown's Planar Intercept Method (Brown 1974), similar to that implemented by Coates et al. (2019). To summarize, this method used down and dead woody debris tallies along planar transects to approximate woody fuel mass. Down and dead woody fuel particles were distinguished based upon time-lag size classes (Cohen and Deeming 1985): 1-hour (0-0.64 cm), 10-hour (0.65-2.54 $\mathrm{cm}), 100$-hour $(2.55-7.62 \mathrm{~cm})$, and 1000-hour $(>7.62 \mathrm{~cm})$. Each transect was $15.2 \mathrm{~m}$ in length with the first transect oriented at $0^{\circ}$, the second at $120^{\circ}$, and the third at $240^{\circ}$ (Fig. 2). Along each transect, 1 - and 10-hour fuels were tallied within the first $1.8 \mathrm{~m}$ and 100 -hour fuels were tallied within the first $3.7 \mathrm{~m}$. One thousand-hour fuels were tallied along the entire $15.2 \mathrm{~m}$ transect and were identified as either hardwood or softwood (Fig. 3). Additionally, a decay class (sound or rotten) was assigned to each 1000-hour fuel based upon that fuel's exterior physical properties (Maser et al. 1979, Lutes et al. 2006). If any portion of a 1000hour fuel's texture appeared soft when kicked, for example, that fuel was classified as rotten. Diameter was measured to the nearest $0.64 \mathrm{~cm}$. Fuel counts were converted to masses using equations developed by Brown (1974) and modified by Coates et al. (2019): 


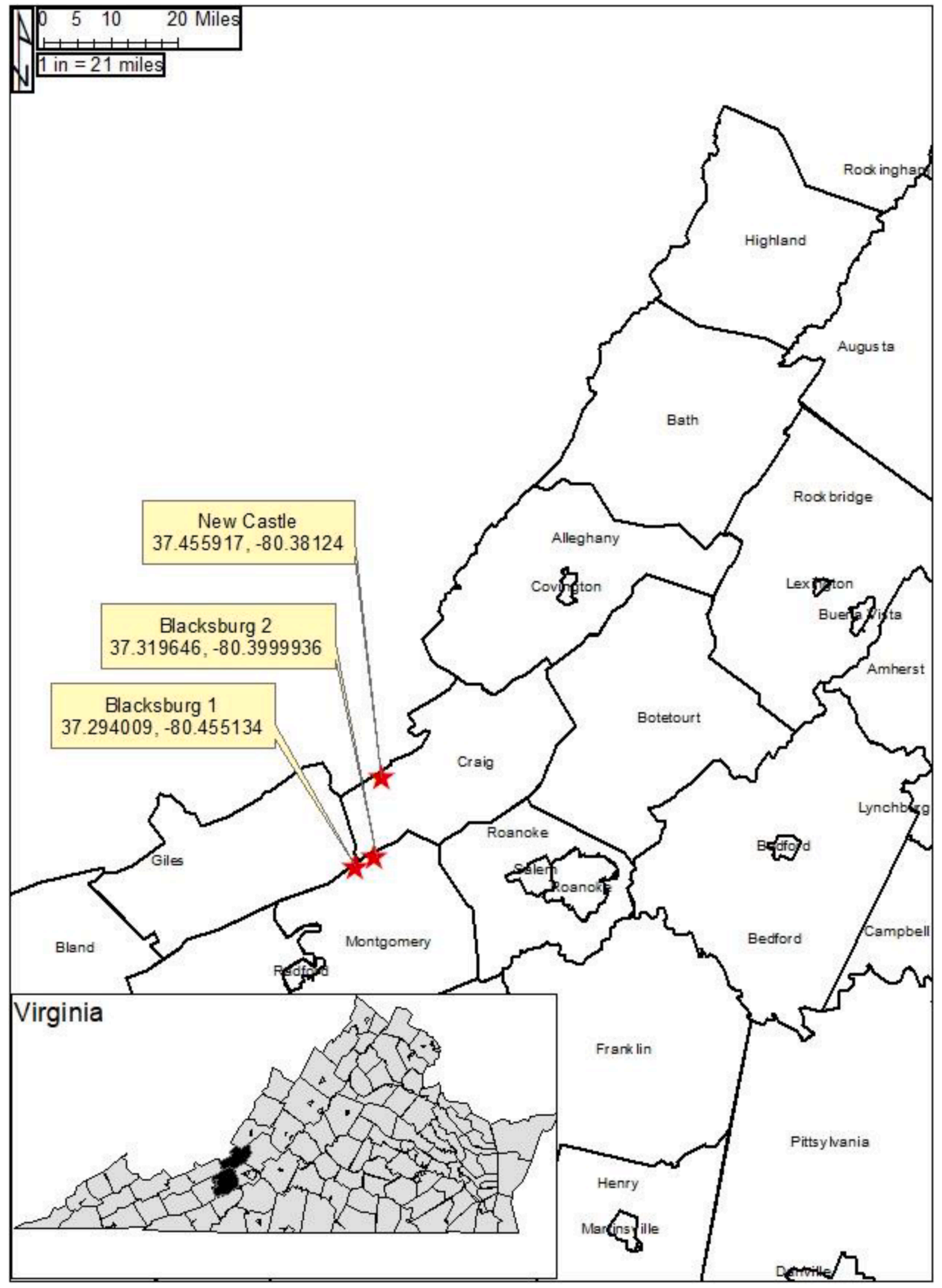

Fig. 1. Study location for the long-term silvicultural study, Ridge and Valley Province, Virginia, USA. 
Table 1

Site descriptions for the Blacksburg 1, Blacksburg 2, and New Castle sites.

\begin{tabular}{|c|c|c|c|c|c|c|}
\hline Site & Predominant Soil Series* & Cover Type ${ }^{\dagger}$ & Average Slope & Aspect & Initial Harvest Year ${ }^{\dagger \dagger}$ & Overwood Removal Year ${ }^{\dagger \dagger}$ \\
\hline Blacksburg 1 & Jefferson & Chestnut Oak & $11 \%$ & Southeast & 1995 & 2007 \\
\hline Blacksburg 2 & Jefferson & Chestnut Oak & $16 \%$ & Southeast & 1996 & 2008 \\
\hline New Castle & Oriskany & Chestnut Oak & $7 \%$ & Southeast & 1996 & 2008 \\
\hline
\end{tabular}

* USDA-NRCS, Web Soil Survey, Montgomery (2015a) and Craig County, VA (2015b).

$\dagger$ Eyre (1980).

i† Hood (2001).

t†† Howell et al. (2021), in preparation.

Table 2

Post-treatment basal area $\left(\mathrm{m}^{2} \mathrm{ha}^{-1}\right)$ for each site following the 1995 and 1996 harvests (Howell et al. 2021, in preparation).

\begin{tabular}{lllll}
\hline Site & Clearcut & $\begin{array}{l}\text { High-retention } \\
\text { Shelterwood }\end{array}$ & $\begin{array}{l}\text { Low-retention } \\
\text { Shelterwood }\end{array}$ & Control \\
\hline $\begin{array}{c}\text { Blacksburg } \\
\mathbf{1}\end{array}$ & 0.89 & 14.33 & 7.78 & 36.97 \\
$\begin{array}{c}\text { Blacksburg } \\
\mathbf{2}\end{array}$ & 2.78 & 17.66 & 5.40 & 35.24 \\
New Castle & 0.57 & 7.53 & 0.00 & 36.92 \\
\hline
\end{tabular}

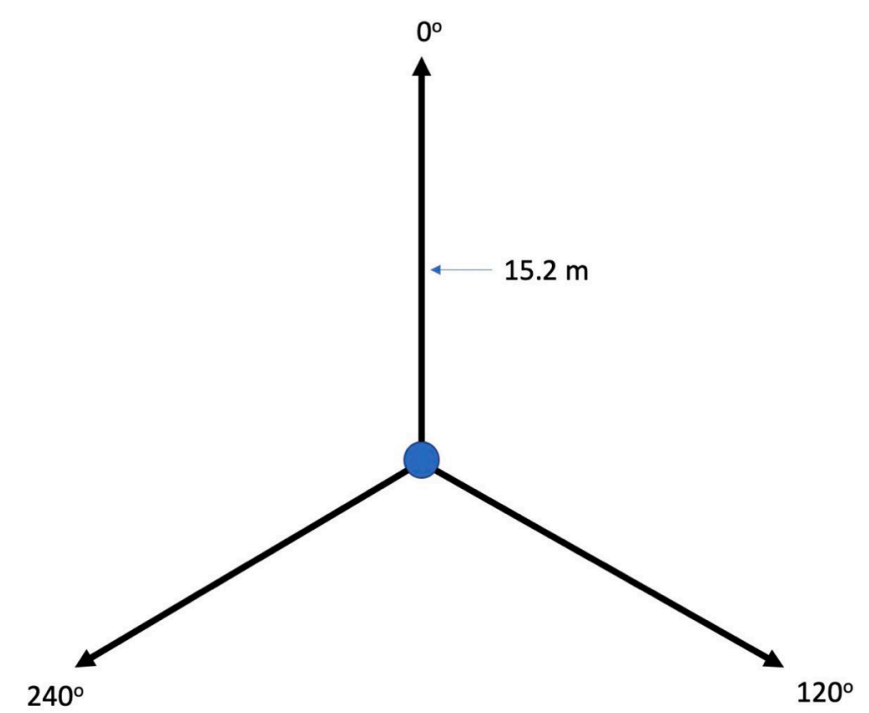

Fig. 2. Fuel transect configuration utilized in this study. Three, $15.2 \mathrm{~m}$ transects were established at $0^{\circ}, 120^{\circ}$, and $240^{\circ}$ around plot center.

For material with diameter $\leq 7.62 \mathrm{~cm}: W$

$$
=2.24\left[(11.64)\left(\mathrm{n} * \mathrm{~d}^{2} * \mathrm{~s} * \mathrm{a} * \mathrm{c}\right) / \mathrm{N} * \mathrm{~L}\right]
$$

For material with diameter $>7.62 \mathrm{~cm} \mathrm{:W}$

$$
=2.24\left[(11.64)\left(\Sigma \mathrm{d}^{2} * \mathrm{~s} * \mathrm{a} * \mathrm{c}\right) / \mathrm{N} * \mathrm{~L}\right]
$$

where:

$2.24=$ conversion factor of tons acre ${ }^{-1}$ to tonnes ha ${ }^{-1}$

$11.64=$ conversion factor of volume to tons acre ${ }^{-1}$

$n=$ the number of woody fuels tallied per timelag-size class

$d=$ quadratic-mean-diameter of particles (in)

$s=$ specific gravity of fuels $(\mathrm{s}=0.70,0.58,0.58$, and 0.30 for 1 - and

10-hour, 100-hour, 1000-hour sound, and 1000-hour rotten material, respectively) (Anderson, 1982)

$a=$ non-horizontal angle factor correction factor

$c=$ slope correction factor

$N=$ number of transects at each plot $(\mathrm{N}=3)$

$L=$ length (ft) of sampling plane ( $\mathrm{L}=6$ for 1 - and 10-hour fuels; $\mathrm{L}=$
12 for 100-hour fuels; and $\mathrm{L}=50$ for 1000-hour fuels)

Non-horizontal angle correction factor values from Brown (1974) were used in these equations. Slope percent is factored into this equation; therefore, slope was measured using a Suunto clinometer (percent scale) along each transect.

Litter (Oi Horizon), duff (Oe + Oa Horizons), and woody fuel depth (defined as the length from the top of the Oi horizon to the top of a down and dead woody fuel particle lying along a planar transect) were measured at 3.7, 7.6, and $12 \mathrm{~m}$ along each linear transect. Additionally, litter and duff were destructively sampled within a $0.09 \mathrm{~m}^{2}$ PVC plastic frame to determine the O Horizon load (Coates et al. 2020). Along each transect, one sample was collected at the end of the $120^{\circ}$ and $240^{\circ}$ transects and one sample was collected within $1.5 \mathrm{~m}$ of the origin for the $0^{\circ}$ transect. This yielded three destructive samples of litter and duff per plot. Litter and duff samples were oven-dried for at least $72 \mathrm{~h}$ at $65^{\circ} \mathrm{C}$, then mass was recorded to the nearest $0.1 \mathrm{~g}$.

\subsection{Fuel data analysis}

The fuels data failed to meet the equal variance assumption for oneway analysis of variance (ANOVA). Therefore, a square root transformation was applied to all woody fuel masses except sound and rotten 1000-hour fuels which were transformed by square and cube root transformations, respectively. Additionally, a $\log (\mathrm{x}+1)$ transformation was applied to the litter and duff masses, depths, and dead woody fuel depth.

An ANOVA was conducted for the following fuel load and depth variables: duff mass; litter mass; duff + litter mass; down and dead woody fuel time-lag size class loads (1-hour, 10-hour, 100-hour, 1000hour sound, 1000-hour rotten, and total 1000-hour); total woody fuel load (all down and dead woody fuels); total fuel load (O Horizon load + total woody fuel load); duff depth; litter depth; duff + litter depth; woody fuel depth.

If differences were detected between treatments, a Tukey's Honest Significant Difference (HSD) test was conducted to determine specific differences between treatments. All analyses were conducted using JMP Pro 15 (SAS Institute Inc., Cary, NC, USA). Differences were declared significant at $\alpha=0.05$.

\subsection{Fire behavior modeling}

Fuels data were entered in BehavePlus 6.0.0 (Andrews 2013) for the following variables: a) 1 -hour fuel load (1-hour woody fuel load + litter load, b) 10-hour fuel load, c) 100-hour fuel load, and d) fuel bed depth (litter depth + woody fuel depth). All other variables remained constant for modeling each silvicultural treatment (Fig. 4). Fire behavior estimates were obtained for the following parameters: a) Surface Fire Rate of Spread $\left(\mathrm{m} \mathrm{min}^{-1}\right)$, b) Surface Fireline Intensity $\left(\mathrm{kW} \mathrm{m}^{-1}\right)$, c) Surface Fire Flame Length (m), d) Surface Fire Spread Distance (m), e) Surface Fire Area (ha), f) Surface Fire Perimeter (m). 
$1000-$ hour $(>7.62 \mathrm{~cm})$

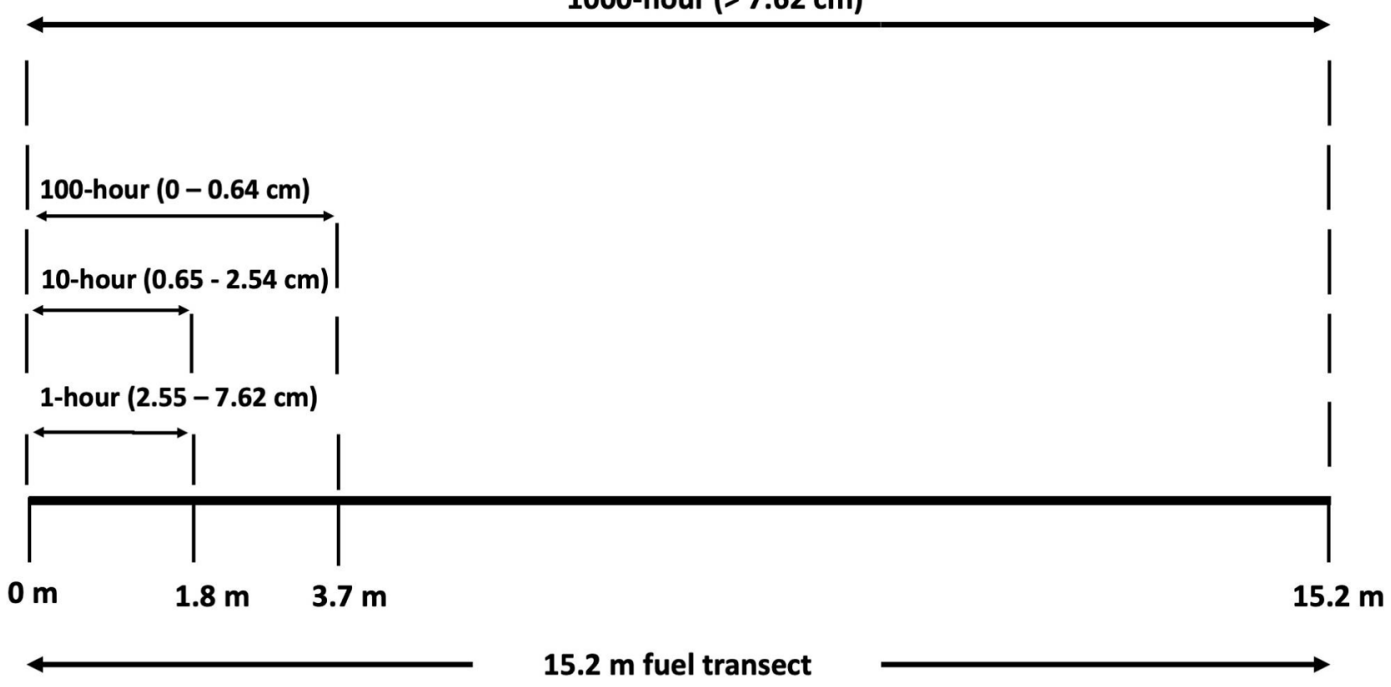

Fig. 3. Sampling lengths utilized along each fuel transect to tally 1-, 10-, 100-, and 1000-hour fuels (Coates et al. 2019).

\section{Results}

\subsection{Fuel loads}

Significant differences in litter and duff loads were present between treatments ( $p<0.0001$ ) (Table 3). Litter and duff loads were highest in the $\mathrm{C}$, but these values did not differ from the CC. Litter loads for the HS treatment were only $76 \%$ of the C values and only $49 \%$ of the duff values. The total $\mathrm{O}$ Horizon load was significantly greater in the $\mathrm{C}$ than all other treatments $(\mathrm{p}<0.0001)$. The silvicultural $\mathrm{O}$ Horizon loads represented the following percentages of the C loads: CC - 75\%, HS $65 \%$, LS - 74\%.

Significant differences in down and dead woody fuel loads between treatments were found in all time-lag size classes except for 100-hour ( $\mathrm{p}$ $=0.4679)$ and 1000-hour sound $(\mathrm{p}=0.3492)$ (Table 3$)$. The CC had the highest 1-hour fuel loads ( $\mathrm{p}=0.0044)$. However, the range of the mean 1 -hour loads was only 0.09 tonnes $\mathrm{ha}^{-1}$. Ten-hour fuel loads were highest in the CC and LS treatments ( $\mathrm{p}<0.0001$ ). The HS and C 10-hour fuel loads represented approximately $60-62 \%$ of the CC and LS 10 -hour fuel loads. Rotten 1000-hour fuel loads were greatest in the $\mathrm{C}(\mathrm{p}=$ 0.0002 ) treatment. The value of the rotten 1000 -hour fuel loads in the $C$ treatment was approximately 3.6 times greater than the CC treatment value, nearly double the value of the HS treatment, and 1.6 times greater than the LS treatment value. Total 1000-hour fuel loads were greatest in the $\mathrm{C}$ when compared to all other treatments $(\mathrm{p}<0.0001)$, more than double the HS and LS values, and nearly quadruple the CC value. Total woody fuel load was greatest in the $C(p=0.0018)$, but was only significantly different from the CC and HS. The CC and HS treatments contained $30 \%$ less woody fuels than the $\mathrm{C}$.

The sum of the $\mathrm{O}$ Horizon load and the down and dead woody fuel load was greatest in the $C$ treatment $(\mathrm{p}<0.0001)$. The silvicultural treatments contained only $65 \%$ (HS), $64 \%$ (LS), and $75 \%$ (CC) of the C total fuel load.

\subsection{Fuel depths}

Duff depth was $51-73 \%$ greater in the $C$ than the silvicultural treatments, resulting in a statistically significant difference between treatments $(\mathrm{p}<0.0001$ ) (Table 4$)$. Litter depth, however, was not significantly different between treatments $(\mathrm{p}=0.2115)$. The total $\mathrm{O}$ Horizon depth was greater $(\mathrm{p}<0.0001)$ in the $\mathrm{C}$ than the treated units. Down and dead woody fuel depth was greater in the C and HS than CC ( $p=0.0081$ ). No difference was found in woody fuel depth between the
LS and the other treatments.

\subsection{Fire behavior estimation}

Fuels data entered in BehavePlus 6.0.0 are listed in Table 5. Values for the 6 estimated fire behavior parameters were greatest for $\mathrm{C}$, with the exception of surface fire flame length (Table 6). This value did not differ between the LS and C. Values for all parameters were lowest for the CC and were between 46.0 and $87.3 \%$ lower than C estimates. The HS had the second highest reductions for each parameter, between 7.7 and $25.2 \%$ less than the C. Values for LS were most closely aligned with C values $(0-16.4 \%$ reductions $)$.

\section{Discussion}

\subsection{Fuel properties and predicted fire behavior}

Woody fuel, litter, and duff loads in our study (Table 3) were notably lower than others reported in the southern Appalachian Mountains (Vander Yacht et al. 2019, Coates et al. 2019), however, our fuel loads were comparable to those reported by Brose (2009) in Pennsylvania. These differences emphasize the spatial and temporal variability that may be present for fuel loads between similar ecosystems and ecoregions (Keane et al. 2013). Accounting for potential site-specific differences in these properties currently represents knowledge that is lacking in this region.

The long-term impact of the CC, HS, and LS treatments on fuel loads and depths in the Ridge and Valley Province of Virginia was intricate. These treatments did not universally reduce all fuel properties (Tables 3 and 4 ), as one might assume. One-hour and 10-hour woody fuel loads were not highest in the $\mathrm{C}$ (Table 3). One hundred-hour and 1000-hour sound woody fuel loads did not differ between treatments (Table 3), nor did litter or woody fuel depth (Table 4). A similar lack of differences in 100-hour fuel loads was found by Brose (2016) in a study of shelterwood harvests in the Virginia Piedmont and litter depth has been noted to reaccumulate to pre-harvest levels within 3-4 years postharvest (Graham and McCarthy 2006). This is particularly noteworthy given results suggesting litter is a primary or secondary driver of surface fire behavior in most forest types (Andreu et al. 2012). Duff and litter loads (when measured separately) and the total down and dead woody fuel load were highest in the $\mathrm{C}$, but did not differ statistically with at least one other treatment (Table 3). When these values were taken into account for the BehavePlus entries, only the 1 -hour + litter value was 


\begin{tabular}{|c|c|c|}
\hline \multicolumn{3}{|l|}{ Inputs: SURFACE, SIZE } \\
\hline \multicolumn{3}{|l|}{ Description $\rightarrow \|$} \\
\hline \multicolumn{2}{|l|}{ Fuel/Vegetation, Surface/Understory } & Initialize from a Fuel Model \\
\hline Fuel Model Number & & $\Rightarrow \longdiv { 2 5 6 }$ \\
\hline Fuel Model Code & & $\geqslant 9$ \\
\hline Fuel Load Transfer Portion & $\%$ & $\nabla 0$ \\
\hline Fuel Model Type & & $\rightarrow S$ \\
\hline 1-h Fuel Load & tonne/ha & 3.743643 \\
\hline 10-h Fuel Load & tonne/ha & $\geqslant 1.681277$ \\
\hline 100-h Fuel Load & tonne/ha & 3.855728 \\
\hline Live Herbaceous Fuel Load & tonne/ha & $\Rightarrow 0$ \\
\hline Live Woody Fuel Load & tonne/ha & $\nabla 0$ \\
\hline 1-h Fuel SA/V & $\mathrm{m} 2 / \mathrm{m} 3$ & 8202.099738 \\
\hline Live Herbaceous Fuel SA/V & $\mathrm{m} 2 / \mathrm{m} 3$ & P4921.259843 \\
\hline Live Woody Fuel SA/V & $\mathrm{m} 2 / \mathrm{m} 3$ & D4921.259843 \\
\hline Fuel Bed Depth & $\mathrm{m}$ & $\geqslant 0.079248$ \\
\hline Dead Fuel Moisture of Extinction & $\%$ & 25 \\
\hline Dead Fuel Heat Content & $\mathrm{kJ} / \mathrm{kg}$ & 18622.359102 \\
\hline Live Fuel Heat Content & $\mathrm{kJ} / \mathrm{kg}$ & $\geqslant 18622.359102$ \\
\hline \multicolumn{3}{|l|}{ Fuel Moisture } \\
\hline Moisture Scenario & & $\Rightarrow d 211$ \\
\hline \multicolumn{3}{|l|}{ Weather } \\
\hline Midflame Wind Speed (upslope) & $\mathrm{km} / \mathrm{h}$ & $\rightarrow 24.14$ \\
\hline \multicolumn{3}{|l|}{ Terrain } \\
\hline Slope Steepness & $\%$ & $\geqslant 5$ \\
\hline \multicolumn{3}{|l|}{ Fire } \\
\hline Elapsed Time & $\mathrm{h}$ & $\geqslant 3$ \\
\hline
\end{tabular}

Fig. 4. BehavePlus 6.0.0 input for the control treatment. The same values were entered for all variables to compare the fire behavior output for each silvicultural treatment except for: a) 1-hour fuel load, b) 10-hour fuel load, c) 100-hour fuel load, and d) fuel bed depth.

highest in the $\mathrm{C}$ (Table 5). Nevertheless, every approximated fire behavior parameter was highest for the $\mathrm{C}$, with the exception of surface fire flame length in the LS treatment (Table 6). This would suggest that wildfire ignitions occurring at the same time under similar weather conditions in the $\mathrm{C}$ would generate more intense fires that spread more rapidly and require more resources to extinguish. In this regard, it appeared that active forest management, planned and implemented by way of regeneration harvests, reduced the values of the specific, fire behavior parameters that were modeled using a subset of the properties measured during this field study. This is helpful information for forest managers within this region seeking to alter fuel loading and structure, particularly in situations where prescribed fire might be desirable, but a multitude of constraints may limit its use.

Clearcutting resulted in the greatest reductions of approximate fire behavior when compared to the $\mathrm{C}$, despite having the second highest fuel load entered into BehavePlus 6.0.0 (Table 6). The CC treatment did have the lowest fuel bed depth entry (Table 5), therefore it seems logical that the greatest reduction in the fire behavior parameters was most related to a lower fuel bed depth value. O Horizon depth was similar between the silvicultural treatments and differed from the C, but woody 
Table 3

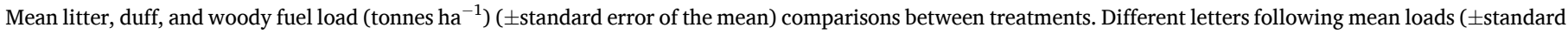
error of the mean) are associated with significant differences within each row $(\alpha=0.05)$.

\begin{tabular}{|c|c|c|c|c|c|}
\hline \multirow[t]{2}{*}{ Fuel Size Class } & \multicolumn{5}{|c|}{ Fuel Loads (tonnes ha ${ }^{-1}$ ) } \\
\hline & $\begin{array}{l}\text { Clearcut } n= \\
48\end{array}$ & $\begin{array}{l}\text { High-retention Shelterwood } n \\
=48\end{array}$ & $\begin{array}{l}\text { Low-retention Shelterwood } n \\
=48\end{array}$ & $\begin{array}{l}\text { Control } n= \\
48\end{array}$ & p-value \\
\hline \multicolumn{6}{|l|}{ O Horizon } \\
\hline Duff Load (Oe + Oa Horizons) & $4.86 \pm(0.37) \mathrm{A}$ & $3.24 \pm(0.23) \mathrm{B}$ & $3.57 \pm(0.26) \mathrm{B}$ & $6.63 \pm(0.61) \mathrm{A}$ & $<0.0001$ \\
\hline Litter Load (Oi Horizon) & $\begin{array}{l}3.23 \pm(0.13) \\
\mathrm{AB}\end{array}$ & $2.63 \pm(0.09) \mathrm{C}$ & $3.00 \pm(0.13) \mathrm{BC}$ & $3.47 \pm(0.15) \mathrm{A}$ & $<0.0001$ \\
\hline Duff + Litter Load (Total O Horizon) & $8.09 \pm(0.41) \mathrm{B}$ & $5.87 \pm(0.26) \mathrm{C}$ & $6.57 \pm(0.34) \mathrm{C}$ & $\begin{array}{l}10.10 \pm(0.62) \\
\text { A }\end{array}$ & $<0.0001$ \\
\hline \multicolumn{6}{|l|}{ Down and Dead Woody Fuels } \\
\hline 1-hour Fuel Load & $0.36 \pm(0.02) \mathrm{A}$ & $0.31 \pm(0.03) \mathrm{B}$ & $0.29 \pm(0.01) B$ & $0.27 \pm(0.02) \mathrm{B}$ & 0.0044 \\
\hline 10-hour Fuel Load & $2.79 \pm(0.18) \mathrm{A}$ & $1.68 \pm(0.14) B$ & $2.70 \pm(0.18) \mathrm{A}$ & $1.69 \pm(0.19) B$ & $<0.0001$ \\
\hline 100-hour Fuel Load & $3.89 \pm(0.36)$ & $3.50 \pm(0.39)$ & $4.45 \pm(0.45)$ & $3.85 \pm(0.36)$ & 0.4679 \\
\hline 1000-hour Rotten Fuel Load & $1.14 \pm(0.23) \mathrm{B}$ & $2.18 \pm(0.35) \mathrm{B}$ & $2.58 \pm(0.60) \mathrm{B}$ & $4.16 \pm(0.49) \mathrm{A}$ & 0.0002 \\
\hline 1000-hour Solid Fuel Load & $0.54 \pm(0.48)$ & $1.02 \pm(0.64)$ & $0.14 \pm(0.9)$ & $2.47 \pm(0.72)$ & 0.3492 \\
\hline Total 1000-hour Fuel Load & $1.68 \pm(0.57) B$ & $3.20 \pm(0.75) \mathrm{B}$ & $2.72 \pm(0.61) \mathrm{B}$ & $6.63 \pm(0.86) \mathrm{A}$ & $<0.0001$ \\
\hline $\begin{array}{l}\text { Total Down and Dead Woody Fuel Load (1-,10-,100- } \\
\text {,1000-hour) }\end{array}$ & $8.72 \pm(0.69) \mathrm{B}$ & $8.69 \pm(0.98) \mathrm{B}$ & $10.16 \pm(0.82) \mathrm{AB}$ & $\begin{array}{l}12.44 \pm(1.05) \\
\text { A }\end{array}$ & 0.0018 \\
\hline \multicolumn{6}{|l|}{ Total Fuel Load } \\
\hline $\begin{array}{l}\text { Total Fuel Load (O Horizon + Down and Dead Woody } \\
\text { Fuels) }\end{array}$ & $16.81 \pm(0.85) \mathrm{B}$ & $14.56 \pm(1.00) \mathrm{B}$ & $16.73 \pm(0.86) \mathrm{B}$ & $\begin{array}{l}22.54 \pm(1.29) \\
\text { A }\end{array}$ & $<0.0001$ \\
\hline
\end{tabular}

Table 4

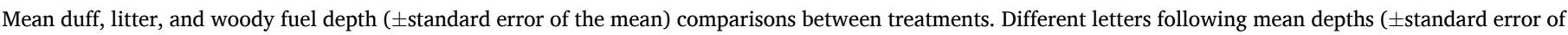
the mean) are associated with significant differences within each row $(\alpha=0.05)$.

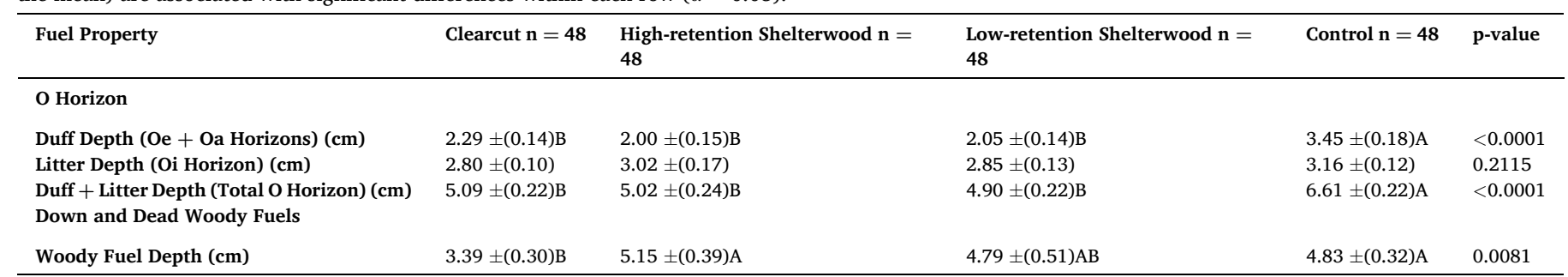

Table 5

Fuel property inputs for BehavePlus 6.0.0, derived from information listed in Tables 3 and 4.

\begin{tabular}{|c|c|c|c|c|}
\hline Fuel Property & Clearcut & $\begin{array}{l}\text { High-retention } \\
\text { Shelterwood }\end{array}$ & $\begin{array}{l}\text { Low-retention } \\
\text { Shelterwood }\end{array}$ & Control \\
\hline $\begin{array}{l}\text { 1-hour + Litter } \\
\text { Fuel Load } \\
\left(\text { tonnes ha }{ }^{-1}\right)\end{array}$ & 3.59 & 2.94 & 3.29 & 3.74 \\
\hline $\begin{array}{l}\text { 10-hour Fuel } \\
\text { Load } \\
\quad\left(\text { tonnes ha }{ }^{-1}\right)\end{array}$ & 2.79 & 1.68 & 2.70 & 1.69 \\
\hline $\begin{array}{l}\text { 100-hour Fuel } \\
\text { Load } \\
(\text { tonnes ha-1) }\end{array}$ & 3.89 & 3.50 & 4.45 & 3.85 \\
\hline $\begin{array}{l}\text { Fuel Bed Depth } \\
\text { (litter depth } \\
\text { + woody fuel } \\
\text { depth) } \\
\text { (m) }\end{array}$ & 0.062 & 0.082 & 0.076 & 0.080 \\
\hline
\end{tabular}

fuel depth was significantly less for the CC than both the C and HS (Table 4). The LS had the highest fuel load entered (Table 5) and produced fire behavior estimates closest to the $C$ values (Table 6). Each fuel load variable entered into BehavePlus was higher for the LS than the HS, even though the 100-hour fuel load was the only variable entered for LS that was highest between all treatments (Table 5). Despite similar timing of the initial harvests and overwood removals, the intensity with which the shelterwood system was implemented impacted approximate fire behavior. Larger, overstory stems were targeted in the LS initial harvest.
Table 6

Fire behavior estimates generated by BehavePlus 6.0.0. Control estimates for each parameter were equal to or greater than estimates for the silvicultural treatments, therefore percentages in each silvicultural treatment cell represent percent reductions of control estimates for that parameter.

\begin{tabular}{|c|c|c|c|c|}
\hline $\begin{array}{l}\text { Fire Behavior } \\
\text { Parameter }\end{array}$ & Clearcut & $\begin{array}{l}\text { High-retention } \\
\text { Shelterwood }\end{array}$ & $\begin{array}{l}\text { Low-retention } \\
\text { Shelterwood }\end{array}$ & Control \\
\hline $\begin{array}{l}\text { Surface Fire } \\
\text { Rate of } \\
\text { Spread } \\
\left(\mathrm{m} \mathrm{min}{ }^{-1}\right)\end{array}$ & $\begin{array}{l}3.4 \\
(69.4 \%)\end{array}$ & $9.2(17.1 \%)$ & $10.1(9.0 \%)$ & 11.1 \\
\hline $\begin{array}{l}\text { Surface } \\
\text { Fireline } \\
\text { Intensity } \\
\left(\mathrm{kW} \mathrm{m}^{-1}\right)\end{array}$ & $\begin{array}{l}102 \\
(79.3 \%)\end{array}$ & 369 (25.2\%) & 465 (5.7\%) & 493 \\
\hline $\begin{array}{l}\text { Surface Fire } \\
\text { Flame } \\
\text { Length } \\
\text { (m) }\end{array}$ & $\begin{array}{l}0.7 \\
(46.2 \%)\end{array}$ & $1.2(7.7 \%)$ & $1.3(0 \%)$ & 1.3 \\
\hline $\begin{array}{l}\text { Surface Fire } \\
\text { Spread } \\
\text { Distance } \\
\text { (m) }\end{array}$ & $\begin{array}{l}608.7 \\
(69.4 \%)\end{array}$ & $1654.1(15.4 \%)$ & $1819.6(8.6 \%)$ & 1990.7 \\
\hline $\begin{array}{l}\text { Surface Fire } \\
\text { Area } \\
\text { (ha) }\end{array}$ & $\begin{array}{l}8.5 \\
(87.3 \%)\end{array}$ & $50.1(25.2 \%)$ & $56.0(16.4 \%)$ & 67.0 \\
\hline $\begin{array}{l}\text { Surface Fire } \\
\text { Perimeter } \\
\text { (m) }\end{array}$ & $\begin{array}{l}1351 \\
(68.2 \%)\end{array}$ & 3559 (16.2\%) & $3881(8.6 \%)$ & 4246 \\
\hline
\end{tabular}


One might hypothesize that the felling and skidding of larger stems in the LS without any preceding harvest operations may have caused more branch breakage in adjacent stems, therefore down and dead woody fuels $\leq 7.62 \mathrm{~cm}$ diameter would be greater in the LS treatment than the HS treatment. This logic did not follow suit for Clatterbuck (2006). In that study, damaged trees increased in harvesting operations with higher retention. This may be a consideration for managers evaluating potential regeneration harvests and their impacts on fuel properties, flammability, and probability of ignition for both wildfires and prescribed fires: differences in initial retention may lead to long-term fire behavior differences.

One thousand-hour woody fuel and duff loads were not accounted for in our BehavePlus models. Their exclusion reduced the total fuel loads by the following percentages per treatment: CC - 39\%, HS - 44\%, LS - 38\%, C - 59\% (Table 3). While not generally consumed during prescribed fire operations in the eastern US, these fuels may be at least partially or completely consumed during wildfire ignitions in this region (Smith and Hagan 2020). Significant duff consumption resulting from wildfires in long-unburned conditions may significantly influence fire behavior and secondary fire effects, such as soil erosion, overstory mortality, and nutrient loss (Fowler 2004, Johnston et al. 2004, Hiers et al. 2005, Ottmar and Andreu 2007, Chojnkaky et al. 2009). As noted previously, duff and total 1000-hour woody fuel loads were highest in the C (Table 3), therefore, one could hypothesize that approximate fire behavior and long-term fire effects would increase if these fuel parameters were factored into BehavePlus predictions. Additionally, no true assessments of canopy openness or light reaching the surface of the ground were recorded in the field. Fuel loading as a stand-alone metric is not entirely adequate for predicting wildland fire behavior. Fuel spatial arrangement, vertical and horizontal continuity, composition, and moisture content also greatly influence wildland fire behavior (Ottmar et al. 2007, Mohr et al. 2010, Thomas et al., 2010, Keane 2015, Rowell et al. 2016, Cruz et al. 2017, Arellano-Pérez et al. 2020). The addition of fuel arrangement and structural assessments in the field and their inclusion in BehavePlus may have impacted the predicted, fire behavior values, likely increasing the values of the $C$ predicted fire behavior parameters due to increased horizontal continuity of the fuel bed.

\subsection{Additional treatments}

No additional treatments, such as prescribed fire or herbicides, were combined with harvesting at these locations. Research investigating the efficacy of prescribed fire combined with mechanical treatments has shown promising results for fuel reduction in the Appalachian Mountains. Waldrop et al. (2010) found significant decreases in 1- and 10hour fuel loads up to 5 years post-treatment in a southern Appalachian hardwood stand. Additionally, modeled fire behavior was lower for each parameter (i.e. rate of spread, flame length, area burned, and spread distance). Furthermore, Graham and McCarthy (2006) observed a decrease in litter and duff following thinning and prescribed fire in Ohio. Reduction in fine fuels was transient, however, as vegetation regenerated and litter re-accumulated. Repeated prescribed fire combined with periodic mechanical treatments may enhance potential reductions of 1-, 10- and 100-hour down and dead woody fuels. However, combination treatments may enhance the shrub layer and potentially increase fire behavior (Waldrop et al. 2010, Phillips and Waldrop 2013, Waldrop et al. 2016). To remedy this, post-fire chemical application or fuel mastication may reduce shrub re-sprouting potential (Romancier 1971, Zedaker et al. 2010). With these studies in mind, it should be understood that other treatments are often utilized alongside harvesting to accomplish multiple site objectives, including fuels management.

\subsection{Ecological considerations}

While our study was focused on fuel loads and predicted fire behavior responses to silvicultural treatments, it is important to consider the implications of harvest operations on other site properties, such as nutrient cycling, water quality, and wildlife. Research suggests that the removal of overstory stems has minimal negative impacts on the abovementioned properties. Twenty years following a clearcut operation at Coweeta Hydrologic Laboratory in North Carolina, Swank et al. (2001) reported that impacts on water yield and nutrient cycling returned to pre-harvest levels within 4 years. Sediment levels, however, were elevated relative to pre-harvest measurements 15 years post-harvest. Benthic community abundance increased in early post-harvest sampling most likely due to changes in stream chemistry and physical properties. Changing site conditions following fuel reduction treatments may affect terrestrial wildlife population dynamics, as well (Gandhi et al. 2008, King et al. 2011). Studies documenting long-term effects of fuel reduction treatments on wildlife populations indicate that different treatments may support different species (Mahoney et al. 2016, Vander Yacht et al. 2016, Greenberg et al. 2017, Greenberg et al. 2018). Management targeted for avian, herpetofaunal, or mammalian species may require adjustments for specific life cycle requirements (Owens et al. 2008). Thus, regeneration harvests to reduce fuels may present an added opportunity to target habitat requirements for specific wildlife species.

While not directly measured, it could logically be inferred that some of the differing fuel loads within the treated units at BB1, BB2, or NC would provide diverse habitat for a host of wildlife species. Therefore, the long-term total fuel load, O Horizon depth, and fire behavior reductions accomplished by the CC, HS, and LS treatments appeared to be holistically feasible and viable within the Ridge and Valley Province of Virginia.

\section{Conclusions}

Long-term reduction of total fuel loading and O Horizon depth was achieved through the use of silvicultural harvests of varying intensities in the Ridge and Valley Province of Virginia. Predicted fire behavior was reduced by way of these treatments when compared to the untreated control and the reductions followed this order: clearcut $>$ high-retention shelterwood > low-retention shelterwood. The removal of mostly overstory stems for the initial cut of the low-retention shelterwood may have increased 10-hour fuel loads within this treatment. The impacts of commonly applied silvicultural treatments on secondary site properties should be considered in conjunction with potential fuel reduction when natural resource management decisions are made. The use of these silvicultural techniques may reduce potential wildfire behavior and effects in areas where prescribed fire is not able to be applied due to the multitude of constraints that often impair its broadcast use.

\section{CRediT authorship contribution statement}

George E. Hahn: Conceptualization, Methodology, Formal analysis, Writing - original draft, Writing - review \& editing, Visualization. T. Adam Coates: Conceptualization, Methodology, Writing - original draft, Writing - review \& editing, Visualization. W. Michael Aust: Conceptualization, Methodology, Writing - review \& editing. M. Chad Bolding: Writing - review \& editing. Melissa A. Thomas-Van Gundy: Writing - review \& editing.

\section{Declaration of Competing Interest}

The authors declare that they have no known competing financial interests or personal relationships that could have appeared to influence the work reported in this paper.

\section{Acknowledgements}

The authors would like to thank Amy Denny, Cora Every, John Kese, Brandon Hughes, and Leah Wood for their assistance in collecting field data. We would also like to thank three anonymous peer reviewers for 
their comments and suggestions that greatly improved the quality of this manuscript prior to submission.

\section{Funding}

Field sampling and data collection in 2019 was funded by the Acorn Alcinda Foundation.

\section{Availability of data and material}

The datasets used and/or analyzed during the current study are available from the corresponding author on reasonable request.

\section{References}

Abatzoglou, J.T., Williams, A.P., 2016. Impact of anthropogenic climate change on wildfire across western US forests. Proc. Natl. Acad. Sci. 113 (42), 11770-11775.

Anderson, H.E. (1982). Aids to determining fuel models for estimating fire behavior. General Technical Report GTR-INT-122, USDA Forest Service Intermountain Forest and Range Experiment Station. (Ogden, UT, USA), 22 p. https://www.fs.fed. us/rm/pubs_int/int_gtr122.pdf.

Andreu, A.G., Shea, D., Parresol, B.R., Ottmar, R.D., 2012. Evaluating fuel complexes for fire hazard mitigation planning in the southeastern United States. For. Ecol. Manage. 273, 4-16.

Andrews, P.L., 2013. Current status and future needs of the BehavePlus Fire Modeling System. Int. J. Wildland Fire 23 (1), 21-33. https://doi.org/10.1071/WF12167.

Arellano-Pérez, S., Castedo-Dorado, F., Álvarez-González, J.G., Alonso-Rego, C., Vega, J. A., Ruiz-González, A.D., 2020. Mid-term effects of a thin-only treatment on fuel complex, potential fire behavior and severity and post-fire soil erosion protection in fast-growing pine plantations. For. Ecol. Manage. 460, 117895 https://doi.org/ 10.1016/j.foreco.2020.117895.

Atwood, C.J., Fox, T.R., Loftis, D.L., 2009. Effects of alternative silviculture on stump sprouting in the southern Appalachians. For. Ecol. Manage. 257 (4), 1305-1313.

Brose, P.H. (2009). Photo guide for estimating fuel loading and fire behavior in mixedoak forests of the Mid-Atlantic region. General Technical Report, NRS-45, USDA Forest Service, Northern Research Station. (Newton, PA, USA).

Brose, P.H. (2016). Consumptions and reaccumulation of forest fuels in oak shelterwood stands managed with prescribed fire. In: 'Proceedings of the 18th biennial southern silvicultural research conference.' e-General Technical Report, SRS-212. USDA Forest Service, Southern Research Station. (Asheville, NC, USA), pp. 191-197.

Brown, J.K. (1974). Handbook for inventorying down woody material. General Technical Report INT-16. USDA Forest Service, Intermountain Forest and Range Experiment Station. (Ogden, UT, USA).

Cascio, W.E., 2018. Wildland fire smoke and human health. Sci. Total Environ. 624 586-595.

Chojnkacky, D., Amacher, M., Gavazzi, M., 2009. Separating duff and litter for improved mass equations. South. J. Appl. For. 33 (1), 29-34.

Clatterbuck, W.K. (2006). Logging damage to residual trees following commercial harvesting to different overstory retention levels in a mature hardwood stand in Tennessee. General Technical Report, SRS-92, USDA Forest Service, Southern Research Station. (Asheville, NC, USA)

Coates, T.A., Waldrop, T.A., Mohr, H.H., Hutchinson, T. (2019). The Appalachian Mountain fuel photo series: A resource for fire managers and practitioners. General Technical Report, SRS-241, USDA Forest Service, Southern Research Station. (Asheville, NC, USA).

Coates, T.A., Johnson, A., Aust, W.M., Hagan, D.L., Chow, A., Trettin, C., 2020. Forest composition, fuel loading, and soil chemistry resulting from 50 years of forest management and natural disturbance in two southeastern Coastal Plain watersheds, USA. For. Ecol. Manage. 473, 188337.

Cohen, J.D, Deeming, J.E. (1985) The national Fire-Danger Rating System: basic equations. USDA Forest Service, Pacific Southwest Forest and Range Experiment Station, General Technical Report PSW-GTR-82. (Berkeley, CA, USA).

Collins, M., Knutti, R. (2013). Chapter 12-Long-term climate change: projections, commitments, and irreversibility. In: Stocker, T.F., Qin, D., Plattner, G., Tignor, M., Allen, S.K., Boschung, J., Nauels, A., Xia, Y., Bex, V., Midgley, M.P. (Eds.), Climate Change 2013: The Physical Science Basis. Contribution of Working Group I to the Fifth Assessment Report of the Intergovernmental Panel on Climate Change. Cambridge University Press, Cambridge, UK and New York, NY, USA. 1535 p. doi. $10.1017 /$ CBO9781107415324

Congressional Research Service. (2018, January 10). Wildfire Management Funding: Background, Issues, and FY2018 Appropriations. https://crsreports.congress.gov/p roduct/pdf/R/R45005.

Cruz, M.G., Alexander, M.E., Plucinski, M.P., 2017. The effect of silvicultural treatments on fire behaviour potential in radiata pine plantations of South Australia. For. Ecol. Manage. 397, 27-38.

Eyre, F.H., 1980. Forest cover types of the United States and Canada. Society of American Foresters, Bethesda, MD, p. 148

Fowler, C.T., 2004. Human health impacts of forest fires in the southern United States: A literature review. J. Ecol. Anthropol. 7 (1), 39-63.

Gandhi, K.J.K., Gilmore, D.W., Katovich, S.A., Mattson, W.J., Zasada, J.C., Seybold, S.J., 2008. Catastrophic windstorm and fuel-reduction treatments alter ground beetle
(Coleoptera: Carabardae) assemblages in a North American sub-boreal forest. For. Ecol. Manage. 256, 1104-1123.

Goodrick, S.L., Achtemeier, G.L., Larkin, N.K., Liu, Y., Strand, T.M., 2012. Modeling smoke transport from wildland fires: a review. Int. J. Wildland Fire 22 (1), 83-94.

Graham, J.B., McCarthy, B.C., 2006. Forest floor fuel dynamics in mixed-oak forests of southeastern Ohio. Int. J. Wildland Fire 15 (4), 479-488.

Greenberg, C.H., Moorman, C.E., Matthews-Snoberger, C.E., Waldrop, T.A., Simon, D., Heh, A., Hagan, D., 2017. Long-term herpetofaunal response to repeated fuel reduction treatments. J. Wildl. Manage. 82 (3), 553-565.

Greenberg, C.H., Tomcho, J., Livings-Tomcho, A., Lanham, J.D., Waldrop, T.A., Hagan, D., 2018. Long-term avian response to fire severity, repeated burning, and mechanical fuel reduction in upland hardwood forest. For. Ecol. Manage. 424, 367-377.

Hammond Jr, D.N. (1997). Characterization of vascular plant species composition and relative abundance in southern Appalachian mixed-oak forests (Doctoral dissertation, Virginia Tech). Retrieved from Virginia Tech Electronic Theses and Dissertations.

Hiers, K.J., Gordon, D.R., Mitchell, R.J., O'Brien, J.J. (2005). Duff consumption and southern pine mortality. U.S. Joint Fire Science Project Final Report, Project 01-1-311. http://jfsp.nifc.gov/projects/01-1-3-11/01-1-3-11_final_report.pdf.

Hood, S.M. (2001). Vegetation responses to seven silvicultural treatments in the southern Appalachians one-year after harvesting. Master's Thesis. Virginia Polytechnic Institute and State University. https://vtechworks.lib.vt.edu/handle/10919/33316.

Howell, R.W., Carter, D.R., Aust, W.M., Copenheaver, C.A. (2021). Regeneration characteristics in central Appalachian hardwoods 23-24 years after implementation of six silvicultural systems in Virginia, USA. In preparation.

Jernigan, P., Gallagher, T., Mitchell, D., Smidt, M., Teeter, L., 2016. High tonnage harvesting and skidding for loblolly pine energy plantations. Forest Products J. 66 (3), 185-191.

Johnston, C.A., Groffman, P., Breshears, D.D., Cardon, Z.G., Currie, W., Emanuel, W., Gaudinski, J., Jackson, R.B., Lajtha, K., Nadelhoffer, K., Nelson, D., Post, W.M., Retallack, G., Wielopsolski, I., 2004. Carbon cycling in soil. Front. Ecol. Environ. 2 (10), 522-528.

Keane, R.E., 2013. Describing wildland surface fuel loading for fire management: a review of approaches, methods and systems. Int. J. Wildland Fire 22 (1), 51-62.

Keane, R.E., 2015. Wildland fuel fundamentals and applications. Springer, New York.

King, D.I., Schlossberg, S., Brooks, R.T., Akresh, M.E., 2011. Effects of fuel reduction on birds in pitch pine-scrub oak barrens of the United States. For. Ecol. Manage. 261, $10-18$.

Kreye, J.K., Varner, J.M., Kobziar, L.N., 2020. Long-duration soil heating resulting from forest floor duff smoldering in longleaf pine ecosystems. Forest Sci. 66 (3), 291-303.

Kupfer, J.A., Terando, A.J., Gao, P., Teske, C., Hiers, J.K., 2020. Climate change projected to reduce prescribed burning opportunities in the south-eastern United States. Int. J. Wildland Fire 29 (9), 764-778.

Liu, J.C., Mickley, L.J., Sulprizio, M.P., Dominici, F., Yue, X., Ebisu, K., Anderson, G.B., Kahn, R.F.A., Bravo, M.A., Bell, M.L., 2016. Particulate air pollution from wildfires in the western U.S. under climate change. Clim. Change 138, 655-666.

Lutes, D.C., Keane, R.E. (2006). Fuel load (FL) sampling method. In 'FIREMON: fire effects monitoring and inventory system.' In: Lutes, D.C., Keane, R.E., Caratti, J.F., Key, C.H., Benson, N.C., Sutherland, S., Gangi, L.J. (Eds.), General Technical Report RMRS-GTR-164-CD USDA Forest Service Rocky Mountain Research Station. (Fort Collins, CO, USA) pp. FL-1-21. https://www.fs.fed.us/rm/pubs/rmrs_gtr164/rmrs gtr164_06_fuel_load.pdf.

Mahoney, K.R., Russell, K.R., Ford, W.M., Rodrigue, J.L., Riddle, J.D., Schuler, T.M., Adams, M.B., 2016. Woodland salamander response to a shelterwood harvestprescribed burn silvicultural treatment within Appalachian mixed-oak forests. For. Ecol. Manage. 359, 277-285.

Maser, C., Anderson, R.G., Cromack, K., Williams, J.T., Cummins, K.W. (1979). Dead and down woody material. In 'Wildlife habitats in managed forests, the Blue Mountains of Oregon and Washington.' (Ed Thomas J.) USDA Forest Service Washington Office Agricultural Handbook 553. (Washington, DC, USA).

McIver, J., Youngblood, A., Stephens, S.L., 2009. The national Fire and Fire Surrogate study: ecological consequences of fuel reduction methods in seasonally dry forests. Ecol. Appl. 19 (2), 283-284.

Mitchell, R.J., Liu, Y., O'Brien, J.J., Elliott, K.J., Starr, G., Miniat, C.F., Hiers, J.K., 2014 Future climate and fire interactions in the southeastern region of the United States. For. Ecol. Manage. 327, 316-326.

Mohr, H.H., Waldrop, T.A., Simon, D.M. (2010). Using BEHAVEPlus for predicting fire behavior in southern Appalachian hardwood stands subjected to fuel reduction treatments, In: Stanturf, John A., ed. 2010. Proceedings of the 14th biennial southern silvicultural research conference. Gen. Tech. Rep. SRS-121. Asheville, NC: U.S. Department of Agriculture, Forest Service, Southern Research Station. 565-567.

Moody, J.A., Martin, D.A., 2009. Synthesis of sediment yields after wildland fire in different rainfall regimes in the westerns United States. Int. J. Wildland Fire 18 (1), 96-115.

O’Brien, J.J., Hiers, J.K., Mitchell, R.J., Varner, J.M., Mordecai, K., 2010. Acute physiological stress and mortality following fire in a long-unburned longleaf pine ecosystem. Fire Ecol. 6 (12), 1-12.

Ottmar, R.D., Sandberg, D.V., Riccardi, C.L., Prichard, S.L., 2007. An overview of the fuel characteristic classification system-quantifying, classifying and creating fuelbeds for resource planning. Can. J. For. Res. 37 (12), 2383-2393.

Ottmar, R.D., Andreu, A. (2007). Litter and bulk densities in the southern United States. U.S. Joint Fire Science Program Final Report, Project 04-2-1-49. https://www.fir escience.gov/projects/04-2-1-49/project/04-2-1- 49_final_report.pdf. 
Owens, A.K., Moseley, K.R., McCay, T.S., Castleberry, S.B., Kilgo, J.C., Ford, W.M., 2008. Amphibian and reptile community response to coarse woody debris manipulations in upland loblolly pine (Pinus taeda) forests. For. Ecol. Manage. 256, 2078-2083.

Phillips, R.J., Waldrop, T.A. (2013). Fuel loading following fuel-reduction treatments and impacts from natural disturbances. In: 'Proceedings of the 15th biennial southern silvicultural research conference'. e-General Technical Report SRS-175, USDA Forest Service, Southern Research Station. (Asheville, NC, USA), pp. 533-540.

Prestemon, J.P., Shankar, U., Xiu, A., Talgo, K., Yang, D., Dixon, E., McKenzie, D., Abt, K. L., 2016. Projecting wildfire area burned in the south-eastern United States, 2011-60. Int. J. Wildland Fire 25, 715-729.

Robichaud, P.R., Wagenbrenner, J.W., Brown, R.E., Wolhgemuth, P.M., Beyers, J.L., 2008. Evaluating the effectiveness of contour-felled log erosion barriers as a post-fire runoff and erosion mitigation treatment in the western United States. Int. J. Wildland Fire 17 (2), 255-273.

Robichaud, P.R., Rhee, H., Lewis, S.A., 2014. A synthesis of post-fire Burned Area Reports from 1972 to 2009 for western US Forest Service lands: trends in wildfire characteristics and post-fire stabilisation treatments and expenditures. Int. J. Wildland Fire 23 (7), 929-944.

Romancier, R.M. (1971). Combining fire and chemicals for the control of rhododendron thickets. Research Note SE-149, USDA Forest Service Southern Forest Experiment Station, Asheville, NC. https://www.srs.fs.usda.gov/pubs/rp/rp_se149.pdf.

Rowell, E., Loudermilk, E.L., Seielstad, C., O'Brien, J.J., 2016. Using simulated 3D surface fuelbeds and terrestrial laser scan data to develop inputs to fire behavior models. Can. J. Remote Sens. 42 (5), 443-459.

Ryan, K.C., Knapp, E.E., Varner, J.M., 2013. Prescribed fire in North American forests and woodlands: history, current practice, and challenges. Front. Ecol. Environ. 11 (s1), e15-e24.

Schweitzer, C.J., Dey, D.C., Wang, Y., 2019. White oak (Quercus alba) response to thinning and prescribed fire in northcentral Alabama mixed pine-hardwood forests. Forest Sci. 65 (6), 758-766.

Smith, C.N., Hagan, D.L., 2020. Assessing the relationship between litter + duff consumption and post-fire soil temperature regimes. Fire 3, 64. https://doi.org/ 10.3390/fire 3040064

Stephens, S.L., Moghaddas, J.J., Edminster, C., Fielder, C.E., Haase, S., Harrington, M., Keelye, J.E., Knapp, E.E., McIver, J.D., Metlen, K., Skinner, C.N., Youngblood, A., 2009. Fire treatment effects on vegetation structure, fuels, and potential fire severity in western U.S. forests. Ecol. Appl. 19 (2), 305-320.

Stottlemyer, A.D., Waldrop, T.A., Wang, G.G., 2015. Prescribed burning and mastication effects on surface fuels in southern pine beetle-killed loblolly pine plantations. Ecol. Eng. 81, 514-524.

Sucre, E.B. (2008). Soil resource heterogeneity and site quality in Southern Appalachian hardwood forests: Impact of decomposing stumps, geology and salamander abundance. Doctoral dissertation. Virginia Polytechnic Institute and State University. https://vtechworks.lib.vt.edu/handle/10919/29470.
Swank, W.T., Vose, J.M., Elliott, K.J., 2001. Long-term hydrologic and water quality responses following commercial clearcutting of mixed hardwoods on a southern Appalachian catchment. For. Ecol. Manage. 143, 163-178.

Thomas, P.A., McAlpine, R.S., Hirsch, K., Hobson, P., 2010. Fire in the forest. Cambridge University Press.

United States Department of Agriculture, Natural Resources Conservation Service. (2015a). Soil Survey of Montgomery County, Virginia. http://soils.usda.gov/ survey/printed_surveys/).

United States Department of Agriculture, Natural Resources Conservation Service. (2015b). Soil Survey of Craig County, Virginia. http://soils.usda.gov/ survey/printed_surveys/).

Vander Yacht, A.L., Keyser, P.D., Buehler, D.A., Harper, C.A., Buckley, D.S., Applegate, R. D., 2016. Avian occupancy response to oak woodland and savanna restoration. J. Wildl. Manag. 80 (6), 1091-1105.

Vander Yacht, A.L., Keyser, P.D., Kwit, C., Stambaugh, M.C., Clatterbuck, W.K., Simon, D.S., 2019. Fuel dynamics during oak woodland and savanna restoration in the Mid-South USA. Int. J. Wildland Fire 28 (1), 70-84.

Varner, J.M., Kreye, J.K., O'Brien, J. (2016). Recent advances in understanding duff consumption and post-fire longleaf pine mortality. In: 'Proceedings of the 18th biennial southern silvicultural conference'. e-General Technical Report SRS-212, USDA Forest Service, Southern Research Station, (Asheville, NC, USA), pp. 335-338.

Vaughan, M.C. (2020). Seasonality of prescribed fire in the southern Appalachians. Master's Thesis, Clemson University. https://tigerprints.clemson.edu/all_theses /3437/.

Waldrop, T.A., Yaussy, D., Phillips, R.J., Hutchinson, T.A., Brudnak, L., Boerner, R.A.J., 2008. Fuel reduction treatments affect vegetation structure of hardwood Forests in western North Carolina and southern Ohio, USA. For. Ecol. Manage. 255 3117-3129.

Waldrop, T.A., Phillips, R.J., Simon, D.A., 2010. Fuels and predicted fire behavior in the southern Appalachian Mountains after fire and fire surrogate treatments. Forest Sci. 56 (1), 32-45.

Waldrop, T.A., Hagan, D.L., Simon, D.M., 2016. Repeated Application of fuel reduction treatments in the southern Appalachian Mountains, USA: implications for achieving management goals. Fire Ecol. 12 (2), 28-47.

Wender, B.W. (2000). The impacts of seven silvicultural alternatives on vascular plant community composition, structure, and diversity in the southern Appalachians. Doctoral dissertation. Virginia Polytechnic Institute and State University. https://v techworks.lib.vt.edu/handle/10919/35653.

Zedaker, S.M., Harrell, C.W., Pearce, C.D. (2010). Effects of prescribed burning, mechanical, and chemical treatments to curtail rhododendron dominance and reduce urban interface fuel loads. U.S. Joint Fire Science Program Final Report, Project 04-2-1-89. https://core.ac.uk/download/pdf/33136508.pdf. 